\title{
What is Post(-)colonialism? Problems with the Definitions
}

\begin{abstract}
There is much continuing debate and disagreement among critics as to the meaning of the term Post(-)colonialism, and indeed even its spelling whether with or without the hyphen. Indeed, agreeing on one simple definition of Postcolonialism is difficult due to many reasons and the dispute over its exact meaning and precise definition seems to be unresolved. The present article is an attempt to define Post(-)colonialism, and thus to point to its major preoccupations and areas of concern. It also aims to draw some debate about the use of the terms "Postcolonial" and "Postcolonial" in some recent publications.

\section{Fakia CHEHBOUB}

Department of Letters and English Language Faculty of Letters and Languages University of Constantine 1 (Algeria)
\end{abstract}

\section{Introduction}

يتصاعد النّاش ويستمر اختلاف الآراء بين

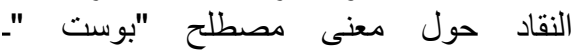
كولونياليسم، وحتى حول طريقة كتابته سواء بالمطّة أو بدونها. إنّ صعوبة الاتفاق حول تعريف و احد للمصنا إسطاح راجعة إلى أسباب عديدة كما أنّ الاختلاف حول حول تعريف موحّد ودقيق لله يبدو بدون حلّ الِّ. وفي هذا الإطار يحاول هذا المقال إيجاد تعريف ليف ليف

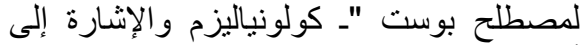
أهم مجالات تخصنصه، كما يهذف بون إلى إنىارة

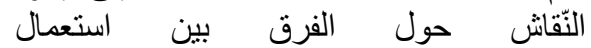

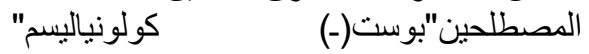

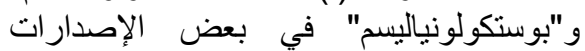

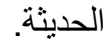

$\mathbf{R}$ major critical discourse in the humanities and ranks together with theories and movements such as Poststructuralism, Psychoanalysis and Feminism. Reaching one simple definition of Postcolonialism does not seem to be an easy task. The debate over the exact meaning and the precise definition of the term still continues and seems to be unresolved. Since colonial experiences have been diverse in different times and places, definitions of Postcolonialism differ. Literally, Postcolonialism is defined as the chronological period that comes after the end of Colonialism. The credibility of this definition has been questioned and challenged because of its simple implication that Colonialism comes to its end. Aijaz Ahmad's critique of Postcolonialism complains that it subordinates the colonised people's history to Colonialism. (1) 


\section{Post-colonialism vs Postcolonialism?}

Generally speaking, there are two main and common definitions. The first one presents a chronological view that regards "Post-colonialism" as an era that begins after the end of Colonialism, while the second one interprets the term as being a longer period that starts at the beginning of the colonial attack. In the first definition the prefix "Post" suggests temporality, and the use of the hyphen emphasises the break between the two periods, the colonial and the post-colonial. Whereas in the second definition the hyphen is absent and the prefix "Post" implies going beyond and transcending Colonialism rather than simply succeeding it. As Stuart Hall says; Postcolonialism "is not only 'after' but 'going beyond' the colonial" (2). Nevertheless, some of the earliest critics of postcolonial theory such as Ella Shohat, argues that the whole idea of a "post" took for granted that Colonialism had been transcended, whereas in fact postcolonial subjects were still controlled by both the colonial institutions and mentalities acting under the guise of globalisation. (3)

According to Simon Gikandi the prefix "post" "marks the desire, by the people who used to be known as colonial subjects, to forget the pain of their immediate history and to imagine a future of freedom outside colonialism, outside nation, outside universal humanism." In her turn, Anne McClintock states that the prefix "Post" "reduces the cultures of peoples beyond colonialism to prepositional time." (5) She continues to say that:

The term confers on colonialism the prestige of history proper; colonialism is the determining marker of history. Other cultures share only a chronological, prepositional relation to a Euro-centered epoch that is over (post-), or not yet begun (pre-) (6).

Yet, the chronological view of Postcolonialism takes for granted the total end of Colonialism. The inadequacies of this interpretation are obvious; the most important objection is that Colonialism cannot be claimed to have an end, as it disguises and can continue in different forms. The economical and cultural influences over the once colonised countries for instance, what is better known as Neocolonialism, is the best example. (7)

\section{Postcolonialism as a Reaction to and Interaction with Colonialism}

Indeed, postcolonial criticism has been defined by Homi Bhabha, one of the founders of this field, as a project that "bears witness to the unequal and uneven forces of cultural representation involved in the contest for political and social authority within the modern world order." (8) Bhabha has argued that the postcolonial perspective emerges "from the colonial testimony of Third World countries and the discourses of 'minorities' within the geopolitical divisions of East and West, North and South" (9). He has debated that in postcolonial criticism, colonial testimony and migrant experiences, together, produce new public discourses, different social agents, and new critical areas; he considered the "newness" of the postcolonial moment excessive of both the imperial and national order and placed it in its marginal relation to them. Thus, Postcolonialism can be best illustrated as a reaction to and interaction with Colonialism since the beginning of the colonial attack; Bill Ashcroft, Gareth Griffith, and Helen Tiffin say that the term "Post-colonial", is used to...cover all the 
culture affected by the imperial process from the moment of colonization to the present day. This is because there is a continuity of preoccupations throughout the historical process initiated by European imperial aggression. (10)

The same writers, in another work, Key Concepts in Post-Colonial Studies, state that the term: "Post-colonialism (or often Postcolonialism) deals with the effects of colonization on cultures and societies". (11)

Interaction with Colonialism, as was said earlier, is a part of Postcolonialism. This interaction usually takes the form of questioning the ideals of Colonialism. For Diana Brydon, "Postcolonialism describes the process of rethinking attitudes toward colonialism and its aftermath, including the terms and categories in which that knowledge has been cast" (12). This rethinking of values and knowledge leads to another part of Postcolonialism, the reaction to and resistance of the colonial rule, mainly represented in literature in nationalist writings.

\section{The Concept of Postcolonialism as Ideological rather than Temporal}

Among the critics who do not accept the chronological version of Postcolonialism are Peter Childs and Patrick Williams. They claim that a "sense of ending, of the completion of one period of history and the emergence of another, is, hard to maintain in any simple or unproblematic fashion" (13). Helen Gilbert and Joanne Tompkins are against the chronological view too, they claim that "Not a naive teleological sequence which supersedes colonialism, post-colonialism is, rather, an engagement with and contestation of colonialism's discourses, power structures, and social hierarchies" (14). Declan Kiberd and Ania Loomba share the same view point. Declan Kiberd emphasises that the beginning of Postcolonialism is not the moment of the occupier's withdrawal; but rather, "that very moment when a native writer formulates a text committed to cultural resistance" (15). In her turn Loomba believes that: "it is more helpful to think of Postcolonialism not just as coming literally after colonialism and signifying its demise, but more flexibly as the contestation of colonial domination and the legacies of colonialism" (16). Elleke Boehmer's view of Postcolonialism is almost the same, he argues that:

Rather than simply being the writing which 'came after' empire, postcolonial literature is that which critically scrutinizes the colonial relationship. It is writing which sets out in one way or another to resist colonialist perspectives. (17)

The chronological view suggests a break in the interactions between the coloniser and the colonised in both periods; the pre-independence and post-independence. It is better to consider the concept of postcoloniality as ideological rather than temporal, in other words, it is better to consider the concept as a move beyond Colonialism both mentally and ideologically rather than succeeding it chronologically. The experiences of the ex-colonised countries reveal that in many cases after the end of Colonialism, the greed of domination is continued in the disguised forms of economic and cultural Colonialism as colonial ways of thinking still exist in these societies. If Postcolonialism is taken just as a historical period marking the end of Colonialism, the emergence of new forms of colonial control cannot be explained. Moreover, the anti-colonial movements starting at beginning of the colonial control could be regarded as symbols 
of postcoloniality, a view that is supported by many critics. For instance, Peter Childes and Patrick Williams debate that:

Texts which are anti-colonial, which reject the premises of colonialist intervention (the civilizing mission, the rejuvenation of stagnant cultures) might be regarded as post-colonial in so far as they have 'got beyond' colonialism and its ideologies, broken free of its lures to a point from which to mount a critique or counter-attack. (18)

Likewise, Jahan Ramazani expresses that the "concept of postcoloniality as resistance to the discourses of colonization has the advantage of recognizing the continuity of oppositional writing before and after independence and of granting political efficacy to postcolonial literatures". (19)

This article is of the same opinion as those critics who believe that Postcolonialism started the beginning of the colonial enterprise, and did not end after the formal independence. Thus, Anti-colonialism is a part of Postcolonialism, except that this later is broader and more diverse, including issues such as Nationalism, resistance, Hybridity, ethnicity, place, language, ...etc. In this sense, Anne McClintock has commented that "Different forms of colonialization have, moreover, given rise to different forms of de-colonization" (20). One can reach the natural conclusion that these different forms of De- colonisation have resulted in different forms of Postcolonialism, so, it is not a homogeneous category. Admitting the heterogeneity of postcolonialism enables and helps us in our discussion of the different cases of former colonised countries.

Ella Shohat asks: "When exactly then does the "post-colonial'begin?" (21) and the historian Arif Dirlik answers "When Third World intellectuals have arrived in First World academe"(22). For him "postcolonial discourse is an ex-pression not so much of agony over identity, as it often appears, but of newfoundpower." (23) These are important questions that are easy to be asked but there are no ready or conclusive answers.

\section{Conclusion}

Postcolonial literature has replaced some descriptive terms as "Commonwealth literature", "Anglophone literature", "and New literature written in English ", "Third World literature and Literature of developing nations". Paul Brians makes a comparison between these terms and he points to their shortcomings. He suggests that "Postcolonial Literature" fits better, though it is not perfect: "We continue to use the term "postcolonial" as a pis aller, and to argue about it until something better comes along". (24)

After all that has been said, attempting to find one single diffinition of Postcolonialism is not as easy as it seems due to the different forms of Colonialism and anticolonial struggles along with the difference between the colonisers and the colonised. The complex and multi-sided nature of the field, not only Postcolonial but also colonial enterprises and anticolonial struggles, calls for new readings that encourage hybridity.

\section{References}


1- Ahmad, Aijaz. In Theory: Classes, Nations, Literatures. London: Verso, 1992. p 15.

2-Hall, Stuart."When Was 'The Postcolonial'? Thinking at the Limit”, in eds., Iain Chambers \& Lidia Curti, The Post-Colonial Question: Common Skies, Divided Horizons .London: Routledge, 1996. p 253.

3- Shohat, Ella. "Notes on the 'PostColonial'," Social Text 31/32 .1992. pp 99-113. http://www.jstor.org/stable/466220?origin=JSTOR-pdf . 20/04/2013.

4 -Gikandi, Simon. "“Postcolonial Theory and the Specter of Nationalism"." CLIO 36.1 (2006): 69+. Indiana University. Web. <www.questia.com>.

5- McClintock, Anne. "The Angel of Progress: Pitfalls of the Term 'Post-colonialism", in ed., Diana Brydon, Postcolonialism: Critical Concepts, vol. I. London and New York: Routledge, 2000. p 177.

6- Ibid177.

7- To use the ironical term "Coca-Colonization", which hints at American ideological and cultural dominance and control over the rest of the world.

8-Bhabha, Homi. The Location of Culture. London: Routledge, 1994. p 171.

9- Ibid 171.

10 -Ashcroft, Bill, Gareth Griffith, and Helen Tiffin, eds. The Empire Writes Back. London: Routledge, 1989.p 2.

11-Ashcroft, Bill et al., Key Concepts in Post-Colonial Studies. London: Routledge, 1998.p186. 12-Brydon. Diana. Postcolonialism: Critical Concepts.vol. I. London: Routledge, 2000.p 4.

13-Childs, Peter and Patrick Williams. An Introduction to Post-Colonial Theory. Harlow: Longman, 1997. $\mathrm{p} 1$.

14- Gilbert, Helen and Joanne Tompkins. Post-Colonial Drama: Theory, Practice, Politics .London: Routledge, 1996. p 2.

15-Kiberd, Declan. Inventing Ireland: The Literature of the Modern Nation. London: Vintage, 1996. p6.

16-Loomba, Ania. Colonialism/Postcolonialism. London: Routledge, 1998.p 12.

17-Boehmer, Elleke. Colonial and Postcolonial Literature: Migrant Metaphors. Oxford: Oxford University Press, 1995. p 3.

18- Childes, Peter and Patrick Williams, An Introduction to Post-Colonial Theory, Harlow: Longman, 1997.p 4.

19-Ramazani, Jahan. "Is Yeats a Postcolonial Poet?" in ed., David Pierce, W. B. Yeats Critical Assessments. vol. 4.Mountfield, East Sussex: Helm Information, 2000. p 796.

20 -McClintock, Anne "The Angel of Progress: Pitfalls of the Term 'Post-colonialism", in ed., Diana Brydon, Postcolonialism: Critical Concepts, vol. I. London: Routledge, 2000. P 180.

21- Shohat, Ella. "Notes on the 'PostColonial'," Social Text 31/32 .1992. pp 99-113. p103.

http://www.jstor.org/stable/466220?origin=JSTOR-pdf . 20/04/2013

22- Dirlik, Arif. "The Postcolonial Aura: Third World Criticism in the Age of Global Capitalism." 20- (1994): 328-56. The University of Chicago Press. Web. 20 Apr. 2013. p 329.

23- Ibid 339.

24- Paul Brians, 'Postcolonial Literature': Problems with the Term'. August 7, 1998, http://www.wsu.edu/ brians/anglophone/postcolonial.html 